\title{
Yield and Nutritional Quality of Canola Sprouts
}

\author{
Harbans L. Bhardwaj ${ }^{1}$ and Anwar A. Hamama \\ Agricultural Research Station, Virginia State University, P.O. Box 9061, \\ Petersburg, VA 23806
}

Additional index words. Brassica napus, cruciferae plants, crude fiber content, oil content, protein content

\begin{abstract}
In recent times, the use of sprouted seeds has become popular in human diets. Considerable information is available in the literature about various types of sprouts such as alfalfa, mungbean, and radish. However, information about canola (Brassica napus L.) sprouts, an oilseed crop that is receiving serious consideration as a source of domestic oil for human consumption, is lacking. We studied the composition traits of sprouts made from four canola cultivars ('Banjo', 'KS8200', 'KS8227', and 'Virginia') grown at three locations (Orange, Petersburg, and Suffolk) in Virginia for two crop seasons (2001 to 2002 and 2002 to 2003). Two 20-g seed samples (two replications) of each cultivar $\times$ location combination were sprouted for $6 \mathrm{~d}$ in the laboratory using tap water. Sprouting of canola seeds increased the weight 5.6 times over the original seed weight. Canola sprouts, on average, contained $27.3 \%$ oil, $25.1 \%$ protein, and $10.8 \%$ crude fiber on dry weight basis. Fresh yield of canola sprouts, from $20-\mathrm{g}$ seed, averaged $111.1 \mathrm{~g}$, whereas moisture content averaged $80.3 \%$. Effects of cultivars on fresh sprout yield and moisture content were not significant. Locations where seeds were grown had significant effects on all traits of canola sprouts except for fresh sprout yield. Canola sprouts made from seed of 'Virginia' cultivar had the highest protein content $(\mathbf{2 6 . 2 \%})$, whereas those made from seeds of ' $K S 8227$ ' cultivar had the highest oil content $(28.7 \%)$. Based on traits under study, canola sprouts compared well with alfalfa, brussel sprouts, mungbean, and radish sprouts for overall nutritional quality.
\end{abstract}

Interest in sprouts as a human food has a long history. Chinese and ancient Egyptians, thousands of years ago, consumed sprouts as a healthy food, especially for healing and rejuvenation. Sprouting is a process widely used to improve the nutritional value of legumes and grain seeds. Recently, sprouts have become a popular health food in the United States and other Western countries. Numerous studies have demonstrated that sprouts are one of the most complete and nutritious foods (Bau et al., 1997; Kaur and Kawatra, 2002; Lorenz, 1980; Yang et al., 2001). Sprouts are considered a predigested food with higher biological efficiency values and lower levels of antiphysiological factors than raw or cooked seeds (Balasaraswathi and Sadasivam, 1997; Chung et al., 1989). Sprouts have been observed to contribute extensively to the immune system as excel-

\footnotetext{
Received for publication 9 May 2007. Accepted for publication 5 July 2007.

This research was supported by funds allocated to Virginia State University by National Canola Research Program (Mid-Western Region) of USDA-CSREES through the Southern Illinois University, Carbondale.

Contribution of Virginia State University, Agricultural Research Station, Journal Article Series No. 256.

The use of any trade names or vendors does not imply approval to the exclusion of other products or vendors that may also be suitable.

${ }^{1}$ To whom reprint requests should be addressed; e-mail hbhardwj@vsu.edu.
}

lent detoxificants (Andarwulan et al., 1999; Yang et al., 2001).

Sprouts from seeds of Cruciferae plants such as brussel sprouts, broccoli, and cauliflower (Brassica sp.) are rich in essential nutrients. In addition, they contain substantial quantities of the glucoside-aglycone sulforaphane or 4-methylsulfinylbutyl isothiocyanate, which are very potent inducers of detoxication enzymes and as strong cancer chemopreventive phytochemicals (Chu and Jeffery, 2001; Fahey et al., 1997; Murillo and Mehta, 2001) However, little is known about the nutritional characteristics of canola sprouts. The term "Canola" is a registered trademark of the Canadian Canola Association and refers to cultivars of oilseed rapeseed (Brassica napus L. and B. rapa L.) that produce seed oils with less than $2 \%$ erucic acid and meals with less than $30 \mu \mathrm{mol}$ of aliphatic glucosinolates per gram (Raymer, 2001). Current canola varieties are essentially free of erucic acid and glucosinolates.

The consumer demand and consumption of canola oil in the United States are increasing as a result of its lowest content of saturated fatty acids ( $5 \%$ to $8 \%)$ and moderate content of poly unsaturated fatty acids. However, domestic canola production meets only a small portion of this demand. Research conducted in the mid-Atlantic region has demonstrated that canola can be easily produced in this region and may have an economic advantage over winter wheat. This research has developed suitable germplasm and a production system (Starner et al., 1996, 2002). The efforts to establish canola as an alternate winter crop in this region are hindered by lack of processing facilities. Therefore, development of alternative uses of canola such as on-farm use or development of easily marketable products such as sprouts could help alleviate this problem indirectly by establishing the crop and indirectly helping to increase the availability of this crop as an oilseed.

The objectives of these studies were to determine fresh yield and nutritional quality traits of canola sprouts and to assess the potential of canola sprouts by comparing their composition with literature values of alfalfa, brussel sprouts, mungbean, and radish sprouts.

\section{Materials and Methods}

Mature seeds of four canola (Brassica napus L.) cultivars ('Banjo', 'KS8200', 'KS8227', and 'Virginia') grown during each of 2001 to 2002 and 2002 to 2003 crop seasons at three Virginia locations (Orange, Petersburg, and Suffolk) were used in these studies. These cultivars were common to the National Winter Canola trials in both years. These trials, with three replications per location, included 32 cultivars during 2001 to 2002 and 34 cultivars during 2002 to 2003 crop seasons. During each season, we identified 10 cultivars with highest seed yields based on overall analysis. Seeds from these 10 cultivars in each year from two replications from each of the three locations (60 samples: 10 cultivars $\times$ three locations $\times$ two replications) were used to produce and study sprouts. Four cultivars among these 10 cultivars were common to both seasons. Data from these four cultivars ('Banjo', 'KS8200', 'KS8227', and 'Virginia') from two seasons, three locations, and two replications were used for this submission.

Canola seeds $(20 \mathrm{~g})$, from replications one and two of the original field trial, were sprouted for $6 \mathrm{~d}$ in a wide-mouth jar $(9 \mathrm{~cm} \times$ $9 \mathrm{~cm} \times 16 \mathrm{~cm})$ covered with a mesh screen top to ensure sufficient air ventilation under laboratory conditions $\left(22^{\circ} \mathrm{C}\right.$ temperature and $98 \%$ relative humidity and room lighting, $375 \mathrm{~lx}$ for $10 \mathrm{~h}$ ). After initial hydration (seeds were first soaked in room temperature water overnight), seeds were kept moist by rinsing and draining twice a day and the jars inverted at a slight angle until the next rinse (from 8 to $10 \mathrm{~h}$ ). At the end of sprouting, the fresh weights were recorded and expressed as fresh yield in grams. The sprouts were then dried at $65{ }^{\circ} \mathrm{C}$ until constant weight.

Protein and crude fiber concentrations of sprouts were determined according to AOAC standard methods (AOAC, 1995). The oil was extracted from $2 \mathrm{~g}$ each of ground, dried canola sprouts at room temperature by homogenization with hexane/isopropanol $(3: 2, v / v)$ as described by Hamama et al. (2003). The oil was extracted three times from each sample and bulked to ensure full oil recovery. The oil content was determined gravimetrically after drying under vacuum at $40{ }^{\circ} \mathrm{C}$ and stored under nitrogen at $10^{\circ} \mathrm{C}$ until 
analysis. The oil content was expressed as $\mathrm{g} / 100^{-1} \mathrm{~g}$ dried sprouts.

All data were analyzed by analysis of variance procedures (PROC GLM) in version 6.11 of SAS (SAS, 1996). Least significant difference test was used for mean separation with a significance level of 5\%. The composition data from canola sprouts were compared with the values for alfalfa, brussel sprouts, mungbean, and radish sprouts.

\section{Results and Discussion}

Analysis of variance indicated that growing locations had significant effects on contents of moisture, protein, and crude fiber in canola sprouts, whereas location effects on oil and fresh yield of sprouts were nonsignificant (Table 1). Effects of cultivars were significant only for oil and protein contents in canola sprouts. The cultivar $\times$ location and cultivar $\times$ year interactions were nonsignificant for all traits indicating that means of main effects (cultivars and locations) could be compared statistically.

Canola sprouts contained $27.3 \%$ oil, $25.1 \%$ protein, and $10.8 \%$ crude fiber on a dry weight basis (Table 2). On average, $20 \mathrm{~g}$ of canola seed resulted in $111.1 \mathrm{~g}$ of fresh sprouts, a 5.6 times increase in weight. 'Virginia' was the best cultivar based on protein content $(26.2 \%)$, whereas 'KS8227' cultivar had the highest oil content $(28.7 \%)$. 'Virginia' is a locally adapted, high-yielding cultivar developed at Virginia State University. Highest oil content in canola sprouts was observed when seeds produced at the Suffolk location were used for sprout production, whereas seed produced at the Orange location resulted in lowest oil content in canola sprouts (Table 3 ). These two locations differ in the soil type with the Orange location primarily having clayey soils, whereas the Suffolk location has sandy soils. The Orange location is also known to be cooler than the Suffolk location during canola production (September to June). On the other hand, protein content was the highest in sprouts produced from canola seeds grown at the Petersburg location, which primarily has loamy soils and is intermediate in mean temperatures between the other two locations. The seeds produced at either the Orange or Suffolk locations had similar crude fiber content in the sprouts, both being higher than the content in sprouts produced from seed produced at the Petersburg location.

As stated in the "Materials and Methods," the characterization of canola sprouts is based on four cultivars that were common to National Canola Trials during 2001 to 2002 and 2002 to 2003 crop seasons ('Banjo', 'KS8200', 'KS8227', and 'Virginia'). We had initially studied sprouts made from the 10 highest yielding cultivars from each crop season. Separate analyses of 2001 to 2002 and 2002 to 2003 data (results not presented) indicated that location effects were significant for both crop seasons, the cultivar $x$ location effects were nonsignificant for both years except for protein content during 2002 to 2003 crop season, and cultivar effects were significant during 2001 to 2002 crop season but generally not in 2002 to 2003 crop season. Based on these observations, we conclude that absence of significance among cultivars from analysis of data combined over two crop seasons may be related to the limited number of cultivars. We expect differences among canola cultivars for sprout traits.

A comparison of canola sprouts to alfalfa, brussel sprouts, mungbean, and radish sprouts (Table 4) indicated that canola

Table 1. Analysis of variance (mean squares) for fresh yield and contents of moisture, oil, protein, and crude fiber in sprouts produced from seed of four canola cultivars grown at three locations in Virginia during 2001 to 2002 and 2002 to 2003 crop seasons.

\begin{tabular}{|c|c|c|c|c|c|c|}
\hline Source & $\mathrm{df}$ & Fresh yield & Moisture & Oil & Protein & Crude fiber \\
\hline$\overline{\text { Year }(y)}$ & 1 & $1999.5^{*}$ & $1664.2^{*}$ & 14.5 & $192.6^{* *}$ & 2.4 \\
\hline Rep & 1 & 20.9 & 5.8 & 0.1 & 4.4 & 0.3 \\
\hline $\mathrm{Y} \times \operatorname{rep}\left(\right.$ error $\left._{\mathrm{a}}\right)$ & 1 & 7.4 & 7.8 & 1.9 & 2.4 & 0.1 \\
\hline Location (L) & 2 & 180.9 & $86.9 *$ & 44.8 & $83.4^{* *}$ & $21.4^{*}$ \\
\hline $\mathrm{Y} \times \mathrm{L}$ & 2 & $753.9 *$ & $82.6^{*}$ & 10.8 & $63.8 * *$ & 11.2 \\
\hline $\mathrm{Y} \times \operatorname{rep} \times \mathrm{L}\left(\right.$ error $\left._{\mathrm{b}}\right)$ & 4 & $444.4^{*}$ & 9.8 & 11.1 & 1.8 & 2.1 \\
\hline Cultivars (C) & 3 & 217.9 & 5.5 & $21.6^{*}$ & $7.3 *$ & 1.3 \\
\hline $\mathrm{L} \times \mathrm{C}$ & 6 & 114.4 & 12.5 & 1.4 & 2.8 & 1.3 \\
\hline $\mathrm{Y} \times \mathrm{C}$ & 3 & 365.3 & 18.0 & 6.5 & 6.6 & 1.2 \\
\hline $\mathrm{Y} \times \mathrm{L} \times \mathrm{C}$ & 6 & 145.0 & 10.9 & 0.4 & 9.6 & 0.9 \\
\hline $\mathrm{Y} \times \operatorname{rep} \times \mathrm{C}$ & 6 & 90.0 & 5.2 & 1.8 & 0.6 & 1.4 \\
\hline Residual error & 12 & 122.1 & 15.1 & 4.7 & 1.9 & 2.3 \\
\hline $\mathrm{R}^{2}(\%)$ & & 86.7 & 92.7 & 83.2 & 96.4 & 79.0 \\
\hline CV $(\%)$ & & 9.9 & 4.8 & 7.9 & 5.5 & 14.1 \\
\hline Mean & & 111.1 & 80.3 & 27.3 & 25.1 & 10.8 \\
\hline
\end{tabular}

${ }^{*, * *}$ Significant at $5 \%$ and $1 \%$ levels, respectively.

Table 2. Fresh yield and contents of moisture, oil, protein, and crude fiber in canola sprouts produced from seeds of four cultivars (means over three locations: Orange, Petersburg, and Suffolk) during each of 2001 to 2002 and 2002 to 2003 crop seasons in Virginia.

\begin{tabular}{lccccc}
\hline Cultivar & Fresh yield $\left(\mathrm{g}^{\mathrm{z}}\right)$ & Moisture $(\%)$ & Oil $(\%)$ & Protein $(\%)$ & Crude fiber $(\%)$ \\
\hline Banjo & $111.9^{\mathrm{y}}$ & 81.3 & 26.9 & 25.0 & 10.5 \\
KS8200 & 111.2 & 80.2 & 28.1 & 24.7 & 10.7 \\
KS8227 & 105.5 & 79.7 & 28.7 & 24.4 & 10.7 \\
Virginia & 115.8 & 80.1 & 25.7 & 26.2 & 11.3 \\
Mean & 111.1 & 80.3 & 27.3 & 25.1 & 10.8 \\
Least significant & & & 1.9 & 1.2 & NS \\
$\quad$ difference (0.05) & NS & NS & & & \\
\hline
\end{tabular}

${ }^{\mathrm{z} F r o m} 20 \mathrm{~g}$ seed. Sampling errors resulted in slight differences between expected and realized fresh weights. Fresh weights were expected to be $20 \mathrm{~g}$ seed + amount of total water imbibed.

${ }^{y}$ Location $\times$ cultivar interaction mean squares for all traits were nonsignificant. Means over 3 locations, 2 years, and two replications.

NsNonsignificant.

Table 3. Location effects on fresh yield and contents of moisture, oil, protein, and crude fiber in canola sprouts from four cultivars (Banjo, KS 8200, KS8227, and Virginia) grown during each of 2001 to 2002 and 2002 to 2003 crop seasons in Virginia.

\begin{tabular}{lccccr}
\hline Location & Fresh yield $\left(\mathrm{g}^{\mathrm{z}}\right)$ & Moisture $(\%)$ & Oil $(\%)$ & Protein $(\%)$ & Crude fiber $(\%)$ \\
\hline Orange & $110.1^{\mathrm{y}}$ & 82.6 & 26.0 & 23.6 & 11.7 \\
Petersburg & 114.8 & 80.4 & 26.8 & 27.7 & 9.5 \\
Suffolk & 108.3 & 77.9 & 29.2 & 23.9 & 11.1 \\
Mean & 111.1 & 80.3 & 27.3 & 25.1 & 10.8 \\
LSD $(0.05)$ & NS & 3.0 & 1.7 & 1.1 & 1.2
\end{tabular}

${ }^{\text {zFrom }} 20 \mathrm{~g}$ seed. Sampling errors resulted in slight differences between expected and realized fresh weights. Fresh weights were expected to be $20 \mathrm{~g}$ seed + amount of total water imbibed.

${ }^{\mathrm{y}}$ Location $\times$ cultivar interaction mean squares for all traits were nonsignificant. Means over four cultivars, 2 years, and two replications.

${ }^{\mathrm{N}}$ Nonsignificant.

Table 4. Comparison of sprouts from canola, alfalfa, radish, and mungbean.

\begin{tabular}{lcccc}
\hline Type & Moisture (\%) & Oil (\%) & Protein (\%) & Crude fiber (\%) \\
\hline Canola $^{\mathrm{z}}$ & 80.3 & 27.3 & 25.1 & 10.8 \\
Alfalfa $^{\mathrm{y}}$ & 91.1 & 7.8 & 45.0 & 25.2 \\
Brussel sprouts $^{\mathrm{y}}$ & 86.0 & 0.3 & 3.4 & 3.8 \\
Mungbean $^{\mathrm{y}}$ & 90.4 & 1.9 & 31.7 & 18.7 \\
Radish $^{\mathrm{y}}$ & 90.1 & 25.5 & 38.4 & - \\
\hline
\end{tabular}

${ }^{\mathrm{z}}$ Average of four cultivars (Banjo, KS8200, KS8227, and Virginia) grown at three locations in Virginia over 2001 to 2002 and 2002 to 2003 crop seasons.

${ }^{y}$ Values from Nutrient Database for Standard Reference, Release 14. USDA-ARS Nutrient Data Laboratory (www.nal.usda.gov/fnic/foodcomp/). 
sprouts contained less moisture than all other sprouts. Canola sprouts contained higher oil content as compared with alfalfa, brussel sprouts, mungbean, and radish sprouts, whereas canola sprouts contained lower amounts of protein and crude fiber than alfalfa, mungbean, and radish sprouts. Canola sprouts contained substantially more protein than that in sprouts of brussel sprouts. Based on these observations, we considered canola seed as potential feedstock for sprout manufacturing. In addition, the canola seeds can be easily available at a lower cost as compared with seeds of the other four crops. These results indicate that canola sprouts may provide nutrition comparable to alfalfa, mungbean, and radish sprouts and their use in the sprout industry may, indirectly, help in establishment of canola as a domestic source of edible and industrial-use oil.

\section{Literature Cited}

Andarwulan, N., D. Fardiaz, G.A. Wattimena, and K. Shetty. 1999. Antioxidant activity associated with lipid and phenolic mobilization during seed germination of Pangium edule Reinw. J. Agr. Food Chem. 47:3158-3163.
AOAC. 1995. Official methods of analysis. 16th ed. Association of Official Analytical Chemists, Arlington, VA.

Balasaraswathi, R. and S. Sadasivam. 1997. Changes in oil, sugars and nitrogenous components during germination of sunflower seeds, Helianthus annuus. Plant Foods Hum. Nutr. 51:71-77.

Bau, H.M., C. Villaume, J.P. Nicolas, and L. Mejean. 1997. Effect of germination on chemical composition, biochemical constituents and antinutritional factors of soya bean (Glycine max) seeds. J. Sci. Food Agr. 73:1-9.

Chu, W.N. and E. Jeffery. 2001. The synergistic upregulation of phase II detoxification enzymes by glucosinolate breakdown products in cruciferous vegetables. Toxicol. Appl. Pharmacol. 174:146-152.

Chung, T.Y., E.N. Nwokolo, and J.S. Sim. 1989. Compositional and digestibility changes in sprouted barley and canola seeds. Plant Foods Hum. Nutr. 39:267-278.

Fahey, J.D., Y. Zhang, and P. Talalay. 1997. Broccoli sprouts: An exceptionally rich source of inducers of enzymes that protect against chemical carcinogens. Proc. Natl. Acad. Sci. USA 94:10367-10372.

Hamama, A.A., H.L. Bhardwaj, and D.E. Starner. 2003. Genotype and growing location effects on phytosterols in canola. J. Amer. Oil Chem. Soc. 80:1121-1126.
Kaur, M. and B.L. Kawatra. 2002. Effect of domestic processing on zinc bioavailability from ricebean (Vigna umbellata) diets. Plant Foods Hum. Nutr. 57:307-318.

Lorenz, K. 1980. Cereal sprouts: Composition, nutritive value, food applications. Crit. Rev. Food Sci. Nutr. 13:353-385.

Murillo, G. and R.G. Mehta. 2001. Cruciferous vegetables and cancer prevention. Nutr. Cancer 41:17-28.

Raymer, P.L. 2001. Canola: An emerging oilseed crop, p. 122-126. In J. Janick and A. Whipkey (eds.). Trends in new crops and uses. ASHS Press, Alexandria, VA.

SAS. 1996. SAS system for Windows. SAS Institute, Inc., Cary, NC.

Starner, D.E., H.L. Bhardwaj, A.A. Hamama, and M. Rangappa. 1996. Canola production in Virginia, p. 287-290. In J. Janick (ed.). Progress in new crops. ASHS Press, Alexandria, VA.

Starner, D.E., A.A. Hamama, and H.L. Bhardwaj. 2002. Prospects of canola as an alternative winter crop in Virginia, p. 127-130. In J. Janick and A. Whipkey (eds.). Trends in new crops and new uses. ASHS Press, Alexandria, VA.

Yang, F., T.K. Basu, and B. Ooraikul. 2001. Studies on germination conditions and antioxidant contents of wheat grain. Int. J. Food Sci. Nutr. 5:319-330. 